\title{
Pamis Learning Model (Acquisition, Natural, Monitoring, Input Filters) In Learning Bugis Language High Grade Of Elementary School
}

\author{
Munirah $^{1}$, Sulfasyah ${ }^{2}$, and Aliem Bahri ${ }^{3}$ \\ \{munirah@unismuh.ac.id ${ }^{1}$, sulfasyah@unismuh.ac.id ${ }^{2}$ \} \\ ${ }^{1}$ Magister of Indonesian Language and Literature Education, Postgraduate of Muhammadiyah University \\ of Makassar. Sultan Alauddin St. No. 259, South Sulawesi, IDN \\ ${ }^{2}$ Magister of Basic Education, Postgraduate of Muhammadiyah University of Makassar. Sultan Alauddin \\ St. No. 259, South Sulawesi, IDN \\ ${ }^{3}$ Education of Elementary School Teachers Department, Muhammadiyah University of Makassar. Sultan \\ Alauddin St. No. 259, South Sulawesi, IDN
}

\begin{abstract}
This study aims to prove the application of the PAMIS learning model in learning Bugis Language in high grade of elementary students. The research design used in this study was a pre-experimental design (One-group Pretest-posttest Design). The study population was high grade of elementary school students. Sampling is done by simple random sampling. The sample in this study, namely the fourth grade of elementary students numbered 22. Data collection techniques in this study are written test and observation techniques. The collected data was analyzed using descriptive statistics and inferential statistics using the t-test formula (paired sample $t$ test). The results prove that Bugis Language learning after using the PAMIS learning model (posttest) is better than Bugis Language Learning before using the PAMIS (Pretest) model after being analyzed using the t test formula, the value of tcount $=2.262$ with df $25, \mathrm{t}$ table $=1,240$. So $\mathrm{t}$ count $\geq \mathrm{t}$ table then the research hypothesis (H1) is accepted. This shows that the use of the PAMIS learning model is effectively applied in the learning of Bugis Language high grade of elementary students in Biring Ere Subdistrict, Pangkep District.
\end{abstract}

Keywords: pamis, learning, model, bugis language

\section{Preliminary}

Based on the Minister of Education and Culture Regulation no.79/2014 concerning the 2013 curriculum article 2 that local content is the subject of study or subjects in an educational unit that contains content and learning processes about local potential and uniqueness that are intended to shape students' understanding of excellence and wisdom in the area of residence.

Based on preliminary observations that the learning of Bugis Regional Languages that the development of vocabulary, reading and writing Lontara script in high classes, learning outcomes do not reach the specified KKM standards. The ability to write Lontara script is categorized as medium (65\%), the ability to read Lontara script is low $(10 \%)$, the learning model used by the teacher has not been effective using the direct learning model. Therefore, it is necessary to change the learning model so that students are motivated to learn and pay close attention to the material provided. Interest and enthusiasm in reading and writing Lontara script increased.

Learning by applying the PAMIS learning model is seen as a model that can improve Bugis Regional Language learning outcomes, because PAMIS has several advantages 
including meaningful learning according to the acquisition of the first language, learning adapted to the material around it. In general the teacher's attitude towards the implementation of Bugis Regional Language learning with the PAMIS learning model, namely (1) Creating a pleasant atmosphere. (2) Appreciating various opinions and building interaction through brainstorming activities. (3) The activeness of students increases. (4) Process and provide relevant learning resources that can support students in participating in learning optimally. (5) Appreciating students' opinions and motivating students to be more enthusiastic and creative in discovering the concepts of the Bugis regional language. (5) Positioning themselves as flexible learning resources to be used by students individually or in groups (Munirah \& Sulfasyah, 2018).

The PAMIS learning model is a Bugis Regional Language learning model based on the Krasyen Monitor theory which is a modification of the Gall, Borg (2003) model. Previous research was designed in the form of research into the development of the Gall, Borg and Gall (2003) model. The results of these modifications produce a learning model of PAMIS type BDB (Munirah and Sulfasyah, 2018). That is, the design of this model develops a Bugis Regional Language based on Krasyen Monitor Theory with patterns of Acquisition, Natural, Monitoring, Input, and Filter. The PAMIS model is implemented in the teaching of high school grade Bugis Language. The stages of the PAMIS learning model are as follows;

- Stage 1: Student orientation in the Acquisition Phase

- The teacher checks the readiness of students;

- The teacher gives an introduction to students, motivates, and opens students' thinking horizons about the subject matter in real life;

- Apperception by holding questions and answers about the language of the Bugis region based on previous experience related to THEMES;

$\circ$ The teacher helps students to 'acquire' the language; and

- The teacher conveys basic potential, themes, and learning material.

- Stage 2: Facilitating students in the Natural Phase

$\circ$ The teacher facilitates students in exploring concepts by studying teaching materials;

- The teacher must begin by introducing relatively easy language concepts;

- Students can 'acquire' the concept naturally;

○ Students do 'scaffolding' to introduce more difficult concepts;

○ The teacher gives assignments to students using LKS;

- Students are grouped.

- Stage 3: Guide students in the Monitoring Phase

- Students are guided by task completion;

- Students receive messages that they can understand;

○ The teacher asks one of the students to present their work and the other students listen;

- The teacher reflects on the learning outcomes;

- The teacher makes comments and rewards the results of the students' assignments;

- The teacher and students discuss the results that have been presented;

- The teacher checks the Lontara script writing errors that have been written by students. 
- Stage 4: Directing students to the Input Phase

- The teacher tests and rearranges the knowledge constructed in the input phase through class discussions;

- The teacher corrects and directs Lontara script written by students;

- The teacher evaluates the success of learning through the percentage / presentation of the work assignments and quizzes.

- Stage 5: Facilitating students in the Filter Phase

- The teacher selectively filters the obstacles in language acquisition;

- Created a conducive environment for students to learn safely and comfortably without feeling afraid or embarrassed in making mistakes and taking risks;

- Teachers guide the implementation of students' tasks in groups and facilitate;

- Students observe the environment and match Lontara script readings with the work of LKS;

- The teacher helps filter learning by evaluating the acquisition of language concepts.

\section{Research Methods}

The design used in this study is pre-experimental design. As for the design used is onegroup pretest design. Before conducting the learning process students are given a pretest for initial ability knowledge. After that students were given posttests after participating in the learning process. Sampling is done by simple ramdom sampling. The sample in this study, namely students in class IV SDN 36 Biring Ere, Pangkep Regency amounted to 22 people. Data collection techniques in this study were written test techniques (assignment / worksheets) and observation. The collected data were analyzed using descriptive statistics and inferential statistics using the t test formula (paired sample $t$ test).

\section{Research Results and Discussion}

The PAMIS learning model towards learning Bugis language in high grade elementary school is associated with the mastery learning of students who get an average value of 65 and above with mastery of $81.81 \%$. The following is a complete table of learning Bugis Language for students.

In accordance with the results of the evaluation at the end of learning Bugis Regional Languages can be seen from the average value of the number of 22 students in grade IV SDN 36 Biring Ere, Pangkep Regency. This shows that in the application of the PAMIS model the average value of the class reached 65 . Classically $81.81 \%$ of students had reached a value of 65 and above, while $13.64 \%$ could not reach a value of 65 . The results that have been assessed during learning that related to Bugis language learning can be seen in the following table. 
Table 4.3 Results of the assessment of Bugis Regional Language learning outcomes.

\begin{tabular}{ccc}
\hline KKM Standard & Total & Percentage \\
\hline$\geq 65$ & 18 students & $81,81 \%$ \\
\hline$<65$ & 4 students & $13,64 \%$ \\
\hline
\end{tabular}

Table 1. Average scores of Bugis Language Ability

\begin{tabular}{cccc}
\hline No & Type of Ability & $\begin{array}{c}\text { Cumulative Average } \\
\text { Value }\end{array}$ & Percentage \\
\hline 1 & Listening & 90 & $90,90 \%$ \\
\hline 2 & Reading & 55 & $81,81 \%$ \\
\hline 3 & Speaking & 75 & $77,27 \%$ \\
\hline 4 & Writing & 80 & $86,36 \%$ \\
\hline
\end{tabular}

Based on the Bugis regional language learning outcomes table above, the average value is very varied from the four types of Bugis regional language skills taught. The ability to listen get an average value of $90(90.90 \%)$, the ability to read an average value of $55(81.81 \%)$, the ability to speak with an average value of $75(77.27 \%)$, and the ability to write an average value averaged $80(86.36 \%)$.

\subsection{Bugis Regional Language Learning Results}

\section{Pretest and Posttest}

\begin{tabular}{lll}
\hline \multicolumn{1}{l}{ Aspects being compared } & Pretest & Postesst \\
\hline & & \\
Mean (average score) & 2,39 & 2,84 \\
Lowest Score & 1,60 & 1,88 \\
Highest Score & 3,04 & 3,48 \\
Completeness with a score of 65 and above & $34,61 \%$ & $81,81 \%$ \\
\hline
\end{tabular}

The results of inferential analysis using the SPSS application show that the value of $\mathrm{t}$ (the difference in pretest and posttest is 2,262 with df 25 . The t table value for df 25 is 1,240 means the value of $t$ count $>t$ table then the null hypothesis (H0) is rejected and the alternative hypothesis (H1 ) accepted so that there are significant differences between classes before using the PAMIS learning model (pretest and after using the PAMIS learning model (posttest). 
Based on the evaluation of results on the implementation of learning by applying the PAMIS model, it was found that basically this PAMIS learning has a good enough potential to improve student learning outcomes towards learning Bugis Regional Languages. This is indicated by the average class results of student tests conducted at the end of learning at each increase. Thus, the PAMIS learning model is a type of learning that can improve student learning outcomes towards learning Bugis Regional Languages specifically speaking and writing in Bugis Regional Languages.

In general, the teacher's attitude towards the implementation of Bugis Regional Language learning with the PAMIS type BDBK learning model is (1) Creating a pleasant atmosphere. (2) Appreciating various opinions and building interaction through brainstorming activities. (3) Process and provide relevant learning resources that can support students in participating in learning optimally. (4) Appreciate students' opinions and motivate students to be more critical and creative in finding Bugis regional language concepts, and (5) Positioning themselves as flexible learning resources to be used by students individually or in groups.

\section{Conclusions and Suggestions}

Overall learning outcomes of students $81.81 \%$. The results of testing the effectiveness of the PAMIS learning model show that the PAMIS learning model meets the effectiveness criteria, that is, the ability of the teacher to manage learning according to the PAMIS learning model is categorized very well. The average percentage of teacher activity in Bugis Language learning activities according to the PAMIS model reaches $90 \%$ (very good category), and the average percentage of student activity is good (80\%). Bugis Language Learning in fourth grade elementary school students before using the PAMIS learning model (pretest) is in the low category. The number of students who got mastery value $34.61 \%$ of 22 students. The learning of Bugis Language for grade IV elementary school students after using the PAMIS learning model (Posttest) is in the good category. The number of students who obtained completeness $(\geq 2.66) 18$ people $(81.81 \%)$ out of 22 students. Based on the results of the analysis the posttest average value is higher than the average pretest value. Through the test formula (paired sample $t$ test), the value of $t$-count $=2,262$ and $t$-table $=1,240$ means the value of t-count> t-table value. This shows that there is a significant difference between pretest and posttest means the research hypothesis is accepted.

To make learning Bugis Language effective, it is necessary to apply a model other than the PAMIS model. The BDBK model needs to be widely tested in the field to determine the effectiveness of the model and teaching materials. Test results of the effectiveness of the model are widely used as material or information in revising and refining the PAMIS learning model operationally.

\section{References}

[1] Brawn, H. Douglas.(2007). Principles of Language Learning and Teaching. Fifth Edition. Longman: San Francisco State University.

[2] Chen, A, (2001). A theoretical Conceptualization for Motivation research in physical education: An integrated perspective. Quest, 53, 35-58.

[3] Chen, A., \& Ennis, C. D. (2004). Goals, interests, and learning in physical education. The Journal of Educational Research, 97, 329-338.

[4] Chen, A., \& Shen, B. (2004). A web of achieving in physical education: Goals, interest, outside-school activity and learning. Learning and Individual Differences, 14, 169-182. 
[5] Dorian, C. (1978). The Ffte of morphological complexity in language death: Evidence from East Sutherland Gaelic. Language, Vol. 54, No. 3: 590-609.

[6] Ennis, C. D., Cothran, D. J., \& Davidson, K. S. (1997). Implementing curriculum within a context of fear and disengagement. Journal of Teaching in Physical Education, 17, 52-71.

[7] Gall, J., Borg. W., \& Gall, M. (2003). Educational research: An introduction (7 $7^{\text {th }}$ ed.). Boston: Pearson Education.

[8] Gega, P. C. 1994. Science in Elementary Education. Sevent Edition. New York: Macmillan Publishing Company.

[9] Gredler, M. E.B. 1991. Belajar dan Membelajarkan (Learning and Instruction Theory Into Practice). Terjemahan oleh Muh Mandir. Jakarta: Rajawali.

[10] Gulzar, M., Gulnaz, F., \& Ijaz, A. (2014). Utility of Krashen's five hypotheses in the Saudi context of foreign language acquisition/learning. English Language Teaching, Vol. 7, No. 8, 134-138.

[11] Gunarwan, A. (2005). Kasus-kasus pergeseran bahasa daerah: Akibat persaingan dengan Bahamas Indonesia. Makalah dalam Kongres MLI XI, Padang.

[12] Hidi, S., \& Harackiewicz, J. M. (2000). Motivating the academically unmotivated: A critical issue for the $21 \mathrm{t}$ century. Review of Educational Research, 70, 151-179.

[13] Joyce, Bruce., \& M. Weil 1992. Model of Teaching. Massachussentts: Allyn and Bacon Publishing Company.

[14] Joyce, Bruce, dkk. 2009. Models of Teaching (Model-Model Pengajaran). Yogyakarta: Pustaka Pelajar.

[15] Krashen, S. (1982). Principles and practice in second language learning and acquisition. Oxford: Pergamon.

[16] Krashen, S. (1985). The input hypothesis: Issues and implications. California: Laredo Publishing Co Inc.

[17] Lipstein, R., \& Renninger, K. A. (2006). "Putting things into words": 12-15 year old students' interest for writing. In P. Boscolo \& S. Hidi (Eds.), Motivation and writing: Research and school practice. New York, NY: Kluwer Academic/Plenum.

[18] Lukman \& Gusnawati. (2013). Rancangan model pembinaan, pengembangan, dan pelestarian bahasa-bahasa daerah di Sulawesi Selatan dari ancaman kepunahan. Disajikan dalam Seminar Antarbangsa II Arkeologi, Sejarah, dan Budaya di Alam Melayu 26 - 27 November 2013, Istitut Alam dan Tamadun Melayu (ATMA) Universitas Kebangsaan Malaysia.

[19] Mangemba, H.D. (2002). Takutlah pada Orang Jujur. Jakarta: Pustaka Pelajar.

[20] Mattulada. H.A. (1998). Sejarah, masyarakat dan kebudayaan Sulawesi Selatan. Bugis: Hasanuddin University Press.

[21] McLaughlin, B. (1987). Theories of second language acquisition. London: Edward Arnold.

[22] Munirah. (2014). Pengembangan Model Pembelajaran Menulis Paragraph Berbasis Konstruktivisme. Makassar: Unhas Makassar.

[23] Munirah \& Sulfasyah (2017). Minat Belajar Bahasa Daerah Murid SD. Laporan Penelitian.

[24] Munirah \& Sulfasyah (2018). Implementasi Teori Krasyan dalam Pembelajaran Bahasa Daerah Bugis.Prosiding . Jakarta: Universitas Muhammadiyah Jakarta.

[25] Munirah \& Sulfasyah (2018). Pengembangan Model Pembelajaran Bahasa daerah Bugis Kelas tinggi SD berdasarkan teori monitor Krasyen sebagai upaya Pelestarian Budaya Lokal melalui Jalur Pendidikan (tahun 1. Laporan Penelitian). 
[26] Pramod, P. N, \& Kad, M. (2013). Understanding the importance of vernacular medium schools in India today. International Journal of Advanced System and Social Engineering Research, Vol 3, Issue 1, 12-17.

[27] Schmidt, Annette. (1985). The fate of ergativity in dying Dyirbal. Language. Vol. 61, No. 2: 378-396. 